\title{
Eating behaviour among nutrition students and social desirability as a confounder
}

\author{
Dóris Freitas, Bruno MPM Oliveira, Flora Correia, Sílvia Pinhão, Rui Poínhos* \\ Faculdade de Ciências da Nutrição e Alimentação da Universidade do Porto, R. Dr. Roberto Frias, 4200-465 Porto, Portugal
}

\section{A R T I C L E I N F O}

\section{Article history:}

Received 27 September 2016

Received in revised form

20 February 2017

Accepted 23 February 2017

Available online 27 February 2017

\section{Keywords:}

Social desirability

Eating behaviour dimensions

Eating self-efficacy

Nutrition students

\begin{abstract}
A B S T R A C T
Introduction: The study of eating behaviour should consider the presence of potential sources of bias, including social desirability. This is particularly relevant among students of Nutrition Sciences, since they have a higher risk of eating disorders.

Objective: To analyse the effect of social desirability in the assessment of eating behaviour dimensions among nutrition students.

Methods: In this cross-sectional study, we analysed data from 149 students of Nutrition Sciences. Participants completed a questionnaire assessing social desirability and eating behaviour dimensions (emotional, external and binge eating, flexible and rigid control, and eating self-efficacy).

Results: Among males, social desirability had a negative association with binge eating, while among women it had a negative association with emotional, external and binge eating and a positive association with eating self-efficacy. In both subsamples, social desirability showed no significant association with any of the two types of dietary restraint (rigid and flexible control).

Discussion: Overall, the association between social desirability and eating behaviour dimensions among students of Nutrition Sciences occurs in the same direction as found in students from other areas. However, alongside these similarities, there is a stronger association between social desirability and binge eating among male students of Nutrition Sciences. We hypothesize that this may be related with the different knowledge of students from different areas, and the way they perceive and face the treatment of eating disorders.

Conclusion: Our study shows that social desirability should be considered while assessing eating behaviour among nutrition students, particularly when studying external eating, binge eating and eating self-efficacy. Moreover, when tailoring interventions to reduce the possible effects of eating behaviour on nutritionists and dieticians' practice, we should consider the influence of social desirability.
\end{abstract}

(c) 2017 Elsevier Ltd. All rights reserved.

\section{Introduction}

Eating behaviour refers to quantitative and qualitative features associated with food selection and consumption (Viana, 2002). It can be influenced by several factors (Grimm \& Steinle, 2011; Quaioti \& Almeida, 2006), including social and cultural factors (Gonçalves, Machado, \& Machado, 2011). Gonçalves et al. (2011) reported that food related professionals, such as nutritionists and dieticians, should be considered at risk of developing eating disorders. Taking into account the impact of this issue on these health

\footnotetext{
* Corresponding author.

E-mail addresses: dorisfreitas@live.com.pt (D. Freitas), bmpmo@fcna.up.pt (B.M. Oliveira), floracorreia@fcna.up.pt (F. Correia), silviapinhao@fcna.up.pt (S. Pinhão), ruipoinhos@fcna.up.pt (R. Poínhos).
}

professionals' performance, studying eating behaviour in this population is relevant.

Eating behaviour can be analysed from two perspectives: the occurrence of eating disorders or the assessment of eating behaviour dimensions. Eating disorders are characterized by significant changes in eating behaviour, associated with excessive concern with weight and body shape (Gonçalves et al., 2011). These have a multifactorial aetiology, involving genetic and sociocultural predispositions as well as biological and psychological vulnerabilities (Morgan, Vecchiatti, \& Negrão, 2002). Nutrition or dietetics students may have a higher risk of presenting these disorders. This has been studied by the scientific community; however, the results have been inconclusive. Some authors found that the risk of eating disorders (Laus, Moreira, \& Costa, 2009; Magdalena \& Julie, 2012; Reinstein, Koszewski, Chamberlin, \& Smith-Johnson, 1992; 
Rosales, Ruíz, Martínez, \& Molina, 2012) or its prevalence (Worobey and Schoenfeld, 1999) is higher among nutrition and dietetics students when compared with students from other areas, while others haven't found significant differences between these two groups (Behar, Alviña, Medinell, \& Tapia, 2007; Fiates \& Salles, 2001; Fredenberg, Berglund, \& Dieken, 1996; Harris, Gee, d'Acquisio, Ogan, \& Pritchett, 2015; Kiziltan \& Karabudak, 2008; Mealha, Ferreira, Guerra, \& Ravasco, 2013; Santos, Meneguci \& Mendonça, 2008; Torresani, 2003). On the other hand, some studies conclude that the predisposition of nutrition and dietetic students to eating disorders is even lower, when compared to medical (Mehr, Clemens, Roach, \& Beech, 1997) or sports students (Nergiz-Unal, Bilgic, \& Yabanci, 2014).

Even considering that nutrition and dietetics is an area prone to a higher prevalence or predisposition of eating disorders, the aetiology of this relationship is not yet fully explained (Mahn \& Lordly, 2015). It is unknown if: a) the higher prevalence of eating disorders is due to a higher attendance of nutrition or dietetics courses by individuals motivated by their experiences on food and weight control; or b) the contact with these issues during the course and the belief that good appearance is important to future professional success is the source of this problem (Fiates \& Salles, 2001; Hughes \& Desbrow, 2005; Penz, Bosco, \& Vieira, 2008).

The use of different methodologies and tools may partially explain the discrepancies found in the literature. Nevertheless, the possibility of higher risk of eating disorders in nutrition or dietetics students deserves attention, as it may have important implications in their performance as students and as future professionals (Houston, Bassler, \& St. Germain, 2015; Santos et al., 2008). Concerning eating behaviour dimensions, the most studied are emotional, external and binge eating and dietary restraint. However, few studies focused on eating behaviour dimensions among nutrition or dietetics students.

Emotional eating is based on the psychosomatic theory (Bruch, 1964), and corresponds to a tendency to overeat as an inappropriate response to negative emotions and distress (Elfhag \& Morey, 2008; van Strien, Herman, \& Verheijden, 2012). External eating derives from the externality theory (Schachter, 1968), and corresponds to eating in response to external food-related cues, such as seeing or smelling food (Elfhag \& Morey, 2008; van Strien et al., 2012). Emotional and external eating have been associated with overeating, weight gain and higher body mass index (BMI; Crockett, Myhre, \& Rokke, 2015; Groesz et al., 2012; Koenders \& van Strien, 2011; Mata, Verdejo-Roman, Soriano-Mas, \& Verdejo-Garcia, 2015; van Strien et al., 2012).

Binge eating has been associated with overeating and with higher BMI. It is mainly characterized by the consumption of a large amount of food in a brief period of time and a sense of lack of control over eating during that episode (Duarte, Pinto-Gouveia, \& Ferreira, 2015; Wolfe, Baker, Smith, \& Kelly-Weeder, 2009).

Unlike the previous dimensions, dietary restraint involves conscious attempts to reduce food intake in order to control body weight (Elfhag \& Morey, 2008; van Strien et al., 2012). Two types of restriction can be considered: flexible control (less strict and associated to a lower disinhibition) and rigid control (which implies dichotomous attitudes regarding which foods to exclude from diet, and is related to a higher disinhibition and higher food consumption after preload; Viana, 2002; Westenhoefer, 1991; Westenhoefer, Broeckmann, Munch, \& Pudel, 1994).

Although not formally considered a dimension of eating behaviour, eating self-efficacy is a good predictor of eating behaviour (AbuSabha \& Achterberg, 1997; Shannon, Bagby, Wang, \& Trenkner, 1990). The concept of self-efficacy was introduced by Bandura (1982) and refers to the beliefs in the ability to organize and implement the action plans needed to achieve a certain result and the feeling of control over behaviours and the environment. It is specific for each task or domain, as for example eating selfefficacy (AbuSabha \& Achterberg, 1997; Hofstetter, Sallis, \& Hovell, 1990). Higher self-efficacy has been associated with lower levels of dietary disinhibition and with lower prevalence of eating disorders (Verstuyf, Patrick, Vansteenkiste, \& Teixeira, 2012).

Some studies assessed these dimensions in nutrition or dietetic students. A study among female students (Magalhães, 2011) found that their diet was mainly determined by external factors. As for restraint, some authors found higher levels of both types on nutrition students when compared to other courses (Korinth, Schiess, \& Westenhoefer, 2010; Poínhos, Alves et al., 2015). This could be related with a higher concern about weight control, since socio-cultural environment and body image appear to be of great importance for this population (Arroyo et al., 2010; Bojórquez, Escalante, López \& Castillo, 2013; Korinth et al., 2010). However, despite their knowledge on nutrition, weight control may not be as successful as expected (Magalhães, 2011; Poínhos, Alves et al., 2015), which may be explained by higher levels of rigid control and binge eating among these students (Poínhos, Alves et al., 2015; Reinstein et al., 1992). As for the remaining dimensions of eating behaviour, Poínhos, Alves, et al. (2015) found no significant differences between nutrition students and those attending other courses.

The study of eating behaviour dimensions may be prone to bias. Social desirability (SD) refers to the tendency to show a culturally acceptable image, in order to avoid negative opinions from others. Individuals with high SD seek approval and avoid criticism when being tested or assessed (Leite \& Beretvas, 2005; Ribas, Moura \& Hutz, 2004). Therefore, some authors argue that this should not be overlooked in studies using self-report measures, because it constitutes a potential source of bias (Leite \& Beretvas, 2005; Poínhos, Oliveira, \& Correia, 2015; Ribas et al., 2004).

The way SD relates to the eating behaviour dimensions is not yet fully elucidated. Concerning emotional, external and binge eating, the associations with SD are negative (Allison \& Heshka, 1993; Hart \& Chiovari, 1998; Poínhos, Oliveira, et al., 2015). Regarding restraint, some authors reported no association with SD (Corrigan \& Ekstrand, 1988; Poínhos, Oliveira, et al., 2015), while Allison et al. (1992) found negative associations $(-0.27 \leq \mathrm{r} \leq-0.21)$ when SD was measured by Edwards scale, although associations were near zero $(|r| \leq 0.08)$ when SD was measured by the Marlowe-Crowne scale. Moreover, Poínhos, Oliveira et al. (2015) reported a positive association between eating self-efficacy and SD.

Students and professionals in the field of nutrition and dietetics may be particularly susceptible to the effects of SD on the assessment of their eating behaviour, based on the idea that their highest level of knowledge in the area should reflect a more normative eating behaviour. However, this notion is only conceptual, as we haven't found studies that analyse eating behaviour among nutrition or dietetics students that evaluate the effects of SD.

Therefore, this work aims to analyse the effect of SD in the assessment of eating behaviour dimensions among nutrition students.

\section{Methods}

\subsection{Sample}

We studied a convenience sample of higher education students attending the undergraduate course of Nutrition Sciences at the Faculty of Nutrition and Food Sciences of the University of Porto. The inclusion criteria were: age between 18 and 27 years old, and the absence of dependency conditions that could constrain free and informed participation. The exclusion of students older than 27 
years of age aimed to reduce socio-demographic heterogeneity, since it is more likely that older students are independent from their origin family.

The sample size was determined by statistical power analysis. Considering a 95\% confidence level, for a sample size of 123 individuals, a correlation above 0.25 would be significant with $80 \%$ power. Since the number of male students is small in the Nutrition Sciences course, we were only able to reach this sample size in the female population. We created a category of students attending the third and fourth years of course due to the respective small sample sizes.

The students were approached in the University, during classes and after previous contact with the responsible teacher. We contacted 215 students, from which 3 (1.4\%) refused to participate. Data from 63 participants (29.7\%) was not analysed since they did not complete their questionnaires. Therefore, we analysed data from 149 students ( 132 females). Several authors reported differences in eating behaviour between sexes (Elfhag and Morey, 2008; Konttinen, Haukkala, Sarlio-Lähteenkorva, Silventoinen, \& Jousilahti, 2009; Poínhos, Rowcliffe et al., 2013; Viana \& Sinde, 2003), hence all the analysis was performed separately for the subsamples of females and males.

\subsection{Procedure}

This study was conducted according to the guidelines of the Declaration of Helsinki and was approved by the ethics committee of Centro Hospitalar de São João, E.P.E. (Porto, Portugal). Data were collected between February and July 2012. All procedures were standardized prior to data collection. Students were invited to participate, and we provided a written document with the study's conditions of participation, aims and overall description. After clarifying doubts, we obtained the written informed consent from all students willing to participate. Then, the participants answered a socio-demographic and anthropometric questionnaire. Finally, they filled the eating behaviour and SD questionnaires. All questionnaires were self-administered in a written format, in the presence of an investigator.

\subsection{Measures}

We used the Portuguese version of Dutch Eating Behaviour Questionnaire (Viana \& Sinde, 2003) to measure emotional and external eating. We did not use the DEBQ's restraint scale, as we considered separately the flexible and rigid control of eating behaviour. The flexible and rigid controls of eating behaviour were measured using the subscales proposed by Westenhoefer, Stunkard, and Pudel (1999), recently adapted and validated for Portuguese adults (Poínhos, Rowcliffe et al., 2013). The Portuguese version of these subscales comprises 11 and 14 items respectively. To assess binge eating severity we used the Portuguese version of the Binge Eating Scale (BES) composed of 16 items (Freitas, Lopes, Coutinho, \& Appolinario, 2001). When our study began the BES was not yet adapted for the European Portuguese, and so slight linguistic adjustments were made from the Brazilian Portuguese version (Gormally, Black, Daston, \& Rardin, 1982; Tapadinhas \& Ribeiro, 2012). Eating self-efficacy was measured using the General Eating Self-Efficacy Scale (Poínhos, Canelas, Oliveira, \& Correia, 2013). The Portuguese version of Marlowe-Crowne Social Desirability Scale was used to assess SD (Crowne \& Marlowe, 1960; Ribas et al., 2004). BMI was computed based on self-reported weight and height data from the anthropometric questionnaire and classified according to the WHO criteria (2016).

\subsection{Statistical analysis}

Descriptive statistics consists of frequencies (n; \%), means and standard deviations (sd). Normality was assessed using skewness and kurtosis. Due to the positive skewness of BMI and BES, these were log-transformed prior to analysis, although for ease of interpretation, they are presented after exponential conversion to the original scale.

Male and female students were compared regarding their average values on eating behaviour dimensions and SD using independent samples t-tests. We assessed the degree of association between the dimensions of eating behaviour and SD using Pearson's correlation coefficient. In the female subsample, this analysis was also performed by year of course, combining students attending the 3rd and 4th. Additionally, in this subsample we did a covariance analysis (ANCOVA) to study SD effects (factor), year of course (covariate), and interaction between these two variables in each eating behaviour dimension. The effect size was quantified by partial eta squared $\left(\eta_{p}^{2}\right)$, being the effect classified as small $\left(\eta_{p}^{2}<0.030\right)$, medium $\left(0.030 \leq \eta_{p}^{2}<0.100\right)$, or large $\left(\eta_{p}^{2} \geq 0.100\right.$; Cohen, 1988).

All analyses were performed using IBM SPSS Statistics for Windows, version 23.0. Values of p below 0.05 were considered statistically significant.

\section{Results}

\subsection{BMI description and comparison among sexes}

Most of the sample [82.4\% $(n=14)$ of males and $87.9 \%(n=116)$ of females] was classified as having normal weight. In the female subsample, $7.6 \%(n=10)$ were classified as underweight and $4.5 \%$ $(n=6)$ as overweight, more specifically pre-obese, whereas $17.6 \%$ of male $(n=3)$ were pre-obese.

\subsection{Comparison of eating behaviour dimensions and social desirability between sexes}

Table 1 describes and compares eating behaviour and SD between the two subsamples. Female nutrition students present higher SD levels than males. Regarding eating behaviour dimensions, females presented higher scores on external eating. Although without statistical significance, we found a tendency to higher levels of emotional eating in females, whereas males showed higher eating self-efficacy. Concerning binge eating and the two types of restraint, there were no relevant differences between sexes.

\subsection{Associations between social desirability and eating behaviour dimensions}

Table 2 presents the associations between SD and eating behaviour dimensions. In the male subsample, SD showed a

Table 1

Eating behaviour dimensions and social desirability: comparison between sexes.

\begin{tabular}{lllll}
\hline Construct & \multicolumn{2}{l}{ Males $[\mathrm{n}=17]$} & & Females $[\mathrm{n}=132]$ \\
\cline { 2 - 2 } & Mean $\pm \mathrm{sd}$ & & Mean $\pm \mathrm{sd}$ & \\
\hline Social desirability & $14.8 \pm 4.1$ & & $17.3 \pm 4.6$ & 0.028 \\
Emotional eating & $1.8 \pm 0.7$ & & $2.1 \pm 0.8$ & 0.064 \\
External eating & $2.5 \pm 0.6$ & & $2.8 \pm 0.5$ & 0.044 \\
Binge eating & $5.0 \pm 1.2$ & & $4.7 \pm 1.1$ & 0.678 \\
Rigid control & $5.6 \pm 2.3$ & $6.2 \pm 2.7$ & 0.457 \\
Flexible control & $5.4 \pm 2.2$ & $6.2 \pm 2.5$ & 0.218 \\
Eating self-efficacy & $14.4 \pm 3.2$ & $13.1 \pm 3.0$ & 0.099 \\
\hline
\end{tabular}

*Comparison between sexes (independent samples $t$-test). 
Table 2

Associations between social desirability and eating behaviour dimensions.

\begin{tabular}{lll}
\hline Dimension & \multicolumn{2}{l}{ Social desirability } \\
\cline { 2 - 3 } & Males $[\mathrm{n}=17] \mathrm{r}^{*}(\mathrm{p})$ & Females $[\mathrm{n}=132] \mathrm{r}^{*}(\mathrm{p})$ \\
\hline Emotional eating & $-0.229(0.376)$ & $-0.258(0.003)$ \\
External eating & $-0.443(0.075)$ & $-0.364(<0.001)$ \\
Binge eating & $-0.508(0.037)$ & $-0.276(0.001)$ \\
Rigid control & $-0.274(0.286)$ & $-0.055(0.533)$ \\
Flexible control & $0.075(0.775)$ & $0.089(0.308)$ \\
Eating self-efficacy & $0.439(0.078)$ & $0.279(0.001)$ \\
\hline
\end{tabular}

*r: Pearson's correlation coefficient.

negative association with binge eating. Concerning females, SD showed a negative association with emotional, external and binge eating, and a positive association with eating self-efficacy. In both subsamples SD presented no association with restraint (neither with flexible nor with rigid control). Given the small size of the male subsample, the associations between SD and external eating, emotional eating and eating self-efficacy are worth noticing, being in the same direction as observed in the female subsample and with similar absolute values (emotional eating) or even higher (external eating and eating self-efficacy). Similarly, the negative association between SD and rigid control in males, although not significant, has an absolute value that would attain statistical significance in a subsample with the females' size.

\subsection{Associations between social desirability and eating behaviour dimensions among females, by year of course}

Table 3 presents the associations between SD and eating behaviour dimensions in the female subsample by year of course. The same table also presents, for each dimension, the results of an analysis of covariance (univariate ANCOVA). Concerning emotional eating, we observed a negative association only in the group of students of the 3rd and 4th years. As for the other dimensions related to excessive intake, negative associations were also observed for external intake in 1st year students and for binge eating in 2nd year students. With regard to restraint, as for the overall female subsample, we found no association with SD; the two types of restraint are also the only dimensions for which no main effect of SD was found in the ANCOVA. As for eating selfefficacy, there were positive associations with SD for students in the 2nd year and above, with a stronger association among 3rd and 4 th year students. Eating self-efficacy was the dimension with the strongest interaction between year of course and SD (although without statistical significance). We found no main effect of year of course for any of the eating behaviour dimensions.

\section{Discussion}

We aimed to analyse the effect of SD in the evaluation of eating behaviour dimensions among nutrition students. Prior to this analysis, we studied the differences between sexes, and we found that female students had higher levels of SD compared to males. Contrarily to the results obtained in this study, other authors found no significant differences on SD between sexes (Gouveia, Guerra, de Sousa, Santos, \& Costa, 2009; Poínhos, Oliveira, et al., 2015; Ribas et al., 2004).

Regarding external eating, few studies have addressed sex differences in this dimension of eating behaviour. While some didn't find significant differences between sexes (Adriaanse, Evers, Verhoeven, \& de Ridder, 2015; Poínhos, Alves et al., 2015), others, contrarily to our results, found that males presented higher scores on external eating (Snoek, van Strien, Janssens, \& Engels, 2007; van Strien \& Bazelier, 2007). We found only a few studies on this topic, thus, further studies are needed to deepen our knowledge.

When comparing our students with those from other courses in Poínhos, Alves, et al. (2015) and Poínhos, Oliveira, et al. (2015), male nutrition students had on average lower SD scores than those attending other courses (14.8vs. 17.7), while among females the average scores were similar (17.3 vs. 17.7). Given the predominance of female nutrition students, the overall levels of SD among nutrition students of both sexes are similar to those from other courses.

Regarding the effect of SD in the assessment of eating behaviour dimensions, similarly to the results of Poínhos, Oliveira, et al. (2015) among students of other areas, in this study we found that SD was negatively associated with emotional, external and binge eating and positively associated with eating self-efficacy. Several results have not reached statistical significance among males possibly due to the small size of the male subsample.

Alongside with these similarities, we observe some peculiarities in nutrition students, especially in the strength of the associations of eating behaviour dimension with SD. Regarding female students, the eating behaviour dimension with a higher association with SD was external eating, as reported for other courses (Poínhos, Oliveira, et al., 2015). The association strength, for both sexes, are similar to the ones found among students from other courses $\left(r^{2}=13.2 \%\right.$ vs. $11.7 \%$ for females and $19.6 \%$ vs. $17.1 \%$ for males). However, among nutrition students, external eating among males relates more weakly with SD than binge eating $\left(r^{2}=19.6 \%\right.$ for

Table 3

Social desirability, year of course and eating behaviour dimensions (female subsample).

\begin{tabular}{|c|c|c|c|c|c|c|}
\hline \multirow[t]{2}{*}{ Dimension } & \multicolumn{3}{|c|}{ Associations with social desirability } & \multicolumn{3}{|c|}{ Univariated ANCOVA } \\
\hline & $\begin{array}{l}\text { 1st year } \\
{[n=36]} \\
r^{*}(p)\end{array}$ & $\begin{array}{l}\text { 2nd year } \\
{[\mathrm{n}=47]} \\
\mathrm{r}^{*}(\mathrm{p})\end{array}$ & $\begin{array}{l}\text { 3rd and } 4 \text { th years } \\
{[\mathrm{n}=49]} \\
\mathrm{r}^{*}(\mathrm{p})\end{array}$ & $\begin{array}{l}\text { Year } \\
\eta_{p}^{2}(\mathrm{p})\end{array}$ & $\begin{array}{l}\text { SD } \\
\eta_{p}^{2}(\mathrm{p})\end{array}$ & $\begin{array}{l}\text { Year }{ }^{*} \text { SD } \\
\eta_{p}^{2}(\mathrm{p})\end{array}$ \\
\hline Emotional eating & $\begin{array}{c}-0.297 \\
(0.078)\end{array}$ & $\begin{array}{c}-0.158 \\
(0.290)\end{array}$ & $\begin{array}{c}-0.322 \\
(0.024)\end{array}$ & $\begin{array}{c}0.001 \\
(0.946)\end{array}$ & $\begin{array}{c}0.065 \\
(0.004)\end{array}$ & $\begin{array}{c}0.004 \\
(0.792)\end{array}$ \\
\hline External eating & $\begin{array}{c}-0.366 \\
(0.028)\end{array}$ & $\begin{array}{c}-0.381 \\
(0.008)\end{array}$ & $\begin{array}{c}-0.377 \\
(0.008)\end{array}$ & $\begin{array}{c}0.012 \\
(0.479)\end{array}$ & $\begin{array}{c}0.139 \\
(<0.001)\end{array}$ & $\begin{array}{c}0.004 \\
(0.788)\end{array}$ \\
\hline Binge eating & $\begin{array}{c}-0.293 \\
(0.083)\end{array}$ & $\begin{array}{c}-0.344 \\
(0.018)\end{array}$ & $\begin{array}{c}-0.295 \\
(0.040)\end{array}$ & $\begin{array}{c}0.007 \\
(0.655)\end{array}$ & $\begin{array}{c}0.093 \\
(<0.001)\end{array}$ & $\begin{array}{c}0.001 \\
(0.922)\end{array}$ \\
\hline Rigid control & $\begin{array}{c}-0.062 \\
(0.718)\end{array}$ & $\begin{array}{c}-0.140 \\
(0.348)\end{array}$ & $\begin{array}{c}0.027 \\
(0.855)\end{array}$ & $\begin{array}{c}0.007 \\
(0.639)\end{array}$ & $\begin{array}{c}0.004 \\
(0.459)\end{array}$ & $\begin{array}{c}0.005 \\
(0.716)\end{array}$ \\
\hline Flexible control & $\begin{array}{r}-0.045 \\
(0.792)\end{array}$ & $\begin{array}{c}0.002 \\
(0.989)\end{array}$ & $\begin{array}{c}0.278 \\
(0.053)\end{array}$ & $\begin{array}{c}0.016 \\
(0.371)\end{array}$ & $\begin{array}{c}0.006 \\
(0.386)\end{array}$ & $\begin{array}{c}0.022 \\
(0.253)\end{array}$ \\
\hline Eating self-efficacy & $\begin{array}{c}0.051 \\
(0.766)\end{array}$ & $\begin{array}{c}0.342 \\
(0.019)\end{array}$ & $\begin{array}{c}0.486 \\
(<0.001)\end{array}$ & $\begin{array}{c}0.026 \\
(0.195)\end{array}$ & $\begin{array}{c}0.091 \\
(0.001)\end{array}$ & $\begin{array}{c}0.036 \\
(0.097)\end{array}$ \\
\hline
\end{tabular}

*r: Pearson's correlation coefficient; SD: social desirability. 
external eating $v s$. $25.8 \%$ for binge eating), contrarily to what was observed among students from other courses (25.8\% vs. $13.9 \%$ ).

Given the lack of information in the literature to help us understanding these results, we raise two possibilities of interpretation. The fact that binge eating relates more strongly than external eating with SD among male nutrition students (instead of what was observed in male students from other courses) may result from the way binge eating is perceived. Some authors described that this perception appears to differ between sexes (Anderson, GratwickSarll, Bentley, Harrison, \& Mond, 2015; Mond \& Hay, 2008). Mond and Hay (2008), when assessing attitudes and beliefs about binge eating disorder in individuals aged between 15 and 94 years found that women answered that binge eating disorder could be the result of depression, while men believed that it could result primarily from problems with overweight, poor diet, or it could even be due to prior eating behaviour, such as anorexia nervosa or bulimia nervosa. Moreover, in that study, most of the participants who referred that binge eating disorder could be due to dietary causes, also answered that a behavioural program of weight loss, diet and exercise and the contact with a healthcare professional (namely a nutritionist or a dietician) could help solving the problem. Thus, assuming that males are more likely to perceive binge eating disorder (and, as such, high binge eating levels) as a result of a problem with food, and that the solution to this problem will pass by the action of a nutritionist or a dietician, male nutrition students may be particularly susceptible to the effects of SD as they may consider their actions very important for solving this problem. Another possible explanation may arise from the level of knowledge about eating disorders. Male nutrition students have, in general, more knowledge about eating disorders than males attending other courses and, as such, it is more likely that they know that binge eating disorder is more frequent among women (Donald, Black, \& Grant, 2013, p. 228). This could lead male nutrition students to underreport binge eating behaviours as a result of $\mathrm{SD}$ (since they are more common in the opposite sex).

As for the remaining eating behaviour dimensions, emotional eating has associations with SD are similar in magnitude to those of students from other courses, and concerning restraint (rigid and flexible control) there were also no significant associations in either sex.

Regarding eating self-efficacy, the association with SD among nutrition students is stronger in males $\left(r^{2}=19.3 \% v s .11 .1 \%\right.$ among students from other areas) but slightly lower among females $\left(\mathrm{r}^{2}=7.8 \%\right.$ vs. $\left.10.0 \%\right)$. These results are worth being analysed in future studies, including qualitative ones, in order to fully understand their meanings. Since the nutrition course in our University is attended mostly by females, it is worth exploring the potential impact of the minority group effect on male students.

In the stratified analysis by year of course, the positive association of SD with eating self-efficacy tends to be higher throughout the progression on the course. Although not reaching statistical significance, eating self-efficacy was the only dimension where there was a moderate effect of interaction between year of course and SD. This suggests that the increase of knowledge in Nutrition Sciences can lead to a greater SD bias when assessing eating behaviour, considering that the highest level of knowledge in the area should reflect a greater control over their eating behaviour.

This study has some limitations, in particular the fact that the analysis of a convenience sample affects the extrapolation of results. In addition, anthropometric data being self-reported is also a limitation, even with a potentially small influence in the results, as it has been used only to characterize the sample. Despite the relevance of a stratified analysis by year of course, in order to verify whether the increased knowledge of the nutrition students influences in any way the relationships between SD and the dimensions of eating behaviour, this was not possible for males given their small number. For the same reason, it was also not possible to make a separate analysis for students attending the 3rd and 4 th years.

However, despite these limitations, in the absence of studies addressing the influence of SD in the assessment of eating behaviour dimensions among nutrition students, this work gives an important contribution to this area of knowledge. Furthermore, this work may help to create interventions among these students targeted to reduce the possible effects of their own eating behaviour on their practice (namely the clinical one). In particular, we showed that the assessments necessary to tailor these interventions should consider the influence of social desirability. In addition, we highlight as a strength the fact that we could compare the results of this study with those obtained in students from other areas within the same project (using exactly the same tools and procedures).

For future research, and in addition to the qualitative work previously mentioned, we suggest studies with a larger number of participants such that it will be possible to stratify the sample by all years of course for both sexes. Other studies will help to increase our understanding of the impact of increased knowledge in Nutrition Sciences in the relationship between SD and eating behaviour dimensions.

\section{Funding sources}

This research did not receive any specific grant from funding agencies in the public, commercial, or not-for-profit sectors.

\section{References}

AbuSabha, R., \& Achterberg, C. (1997). Review of self-efficacy and locus of control for Nutrition and health-related behaviour. Journal of the American Dietetic Association, 97(10), 1122-1132.

Adriaanse, M. A., Evers, C., Verhoeven, A. A., \& de Ridder, D. T. (2015). Investigating sex differences in psychological predictors of snack intake among a large representative sample. Public Health Nutrition, 21, 1-8.

Allison, D. B., \& Heshka, S. (1993). Social desirability and response bias in selfreports of "emotional eating". Eating Disorders, 1(1), 31-38.

Allison, D. B., Kalinsky, L. B., \& Gorman, B. S. (1992). A comparison of the psychometric properties of three measures of dietary restraint. Psychological Assessment, 4(3), 391-398.

Anderson, R., Gratwick-Sarll, K., Bentley, C., Harrison, C., \& Mond, J. (2015). Adolescents' perception of the severity of binge eating disorder: A populationbased study. Journal of Mental Health, 25(1), 16-22.

Arroyo, M., Basabe, N., Serrano, L., Sánchez, C., Ansotegui, L., \& Rocandio, A. M. (2010). Prevalence and magnitude of body weight and image dissatisfaction among women in dietetics majors. Archivos Latinoamericanos de Nutricion, $60(2), 126-132$.

Bandura, A. (1982). Self-efficacy mechanism in human agency. American Psychologist, 37(2), 122-147.

Behar, A. R., Alviña, W. M., Medinelli, S. A., \& Tapia, T. P. (2007). Trastornos de la conducta alimentaria en estudiantes de la carrera de nutrición y dietética. Revista Chilena de Nutrición, 34(4), 298-306.

Bojórquez, R. M. C., Escalante, M. L. A., López, H. J. V., \& Castillo, D. F. E. (2013). Evaluation of risk factors for eating disorders in students of nutrition. Revista Mexicana de Trastornos Alimentarios, 4(1), 37-44.

Bruch, H. (1964). Psychological aspects of overeating and obesity. Psychosomatics, 5(5), 269-274.

Cohen, J. (1988). Statistical power analysis for the behavioural sciences (2nd ed.). Hillsdale, NJ: Lawrence Erlbaum Associates.

Corrigan, S. A., \& Ekstrand, M. L. (1988). An investigation of the construct validity of the Dutch restrained eating scale. Addictive Behaviors, 13(3), 303-306.

Crockett, A. C., Myhre, S. K., \& Rokke, P. D. (2015). Boredom proneness and emotion regulation predict emotional eating. Journal of Health Psychology, 20(5), $670-680$.

Crowne, D. P., \& Marlowe, D. (1960). A new scale of social desirability independent of psychopathology. Journal of Consulting Psychology, 24, 349-354.

Donald, W., Black, M. D., \& Grant, J. E. (2013). DSM-5 guidebook: The essential companion to the diagnostic and statistical manual of mental disorders (5th ed.). Arlington: American Psychiatric Association.

Duarte, C., Pinto-Gouveia, J., \& Ferreira, C. (2015). Expanding binge eating assessment: Validity and screening value of the binge eating scale in women from the general population. Eating Behaviors, 18, 41-47.

Elfhag, K., \& Morey, L. C. (2008). Personality traits and eating behaviour in the 
obese: Poor self-control in emotional and external eating but personality assets in restrained eating. Eating Behaviors, 9(3), 285-293.

Fiates, G. M. R., \& Salles, R. Kd (2001). Fatores de risco para o desenvolvimento de distúrbios alimentares: um estudo em universitárias. Revista de Nutrição, 14(supplement), 3-6.

Fredenberg, J. P., Berglund, P. T., \& Dieken, H. A. (1996). Incidence of eating disorders among selected female university students. Journal of the American Dietetic Association, 96(1), 64-65.

Freitas, S., Lopes, C. S., Coutinho, W., \& Appolinario, J. C. (2001). Tradução e adaptação para o português da Escala de Compulsão Alimentar Periódica. Revista Brasileira de Psiquiatria, 23, 215-220.

Gonçalves, S. F., Machado, B. C., \& Machado, P. P. P. (2011). O papel dos factores socioculturais no desenvolvimento das perturbacões do comportamento alimentar: uma revisão da literatura. Psicologia Saúde \& Doenças, 12(2), 280-297.

Gormally, J., Black, S., Daston, S., \& Rardin, D. (1982). The assessment of binge eating severity among obese persons. Addictive Behaviors, 7(1), 47-55.

Gouveia, V. V., Guerra, V. M., de Sousa, D. M. F., Santos, W. S., \& Costa, J. M. (2009), Escala de desejabilidade social de Marlowe-Crowne: evidências de sua validade de sua validade fatorial e consistência interna. Avaliação Psicológica, 8, 87-98.

Grimm, E. R., \& Steinle, N. I. (2011). Genetics of eating behaviour: Established and emerging concepts. Nutrition Reviews, 69(1), 52-60.

Groesz, L. M., McCoy, S., Carl, J., Saslow, L., Stewart, J., \& Adler, N. (2012). What is eating you? Stress and the drive to eat. Appetite, 58(2), 717-721.

Harris, N., Gee, D., d’Acquisio, D., Ogan, D., \& Pritchett, K. (2015). Eating disorder risk, exercise dependence, and body weight dissatisfaction among female nutrition and exercise science university majors. Journal of Behavioral Addictions, 4(3), 206-209.

Hart, K. E., \& Chiovari, P. (1988). Inhibition of eating behaviour: Negative cognitive effects of dieting. Journal of Clinical Psychology, 54(4), 427-430.

Hofstetter, C. R., Sallis, J. F., \& Hovell, M. F. (1990). Some health dimensions of selfefficacy: Analysis of theoretical specificity. Social Science and Medicine, 31(9), 1051-1056.

Houston, C. A., Bassler, E., \& St. Germain, A. (2015). Ethical considerations when students experience an active eating disorder during their dietetics training. Journal of the Academy of Nutrition and Dietetics, 115(10), 1715-1717.

Hughes, R., \& Desbrow, B. (2005). Aspiring dietitians study: A pre-enrolment study of students motivations, awareness and expectations relating to careers in nutrition and dietetics. Nutrition and Dietetics, 62(2-3), 106-109.

Kiziltan, G., \& Karabudak, E. (2008). Risk of abnormal eating attitudes among Turkish dietetic students. Adolescence, 43(171), 681-690.

Koenders, P. G., \& van Strien, T. (2011). Emotional eating, rather than lifestyle behaviour, drives weight gain in a prospective study in 1562 employees. Journal of Occupational and Environmental Medicine, 53(11), 1287-1293.

Konttinen, H., Haukkala, A., Sarlio-Lähteenkorva, S., Silventoinen, K., \& Jousilahti, P. (2009). Eating styles, self-control and obesity indicators. The moderating role of obesity status and dieting history on restrained eating. Appetite, 53(1), 131-134.

Korinth, A., Schiess, S., \& Westenhoefer, J. (2010). Eating behaviour and eating disorders in students of nutrition sciences. Public Health Nutrition, 13(1), 32-37.

Laus, M. F., Moreira, RdC. M., \& Costa, T. M. B. (2009). Diferenças na percepção da imagem corporal, no comportamento alimentar e no estado nutricional de universitárias das áreas de saúde e humanas. Revista de Psiquiatria do Rio Grande do Sul, 31(3), 192-196.

Leite, W. L., \& Beretvas, S. N. (2005). Validation of scores on the Marlowe-Crowne Social Desirability Scale and the balanced inventory of desirable responding. Educational and Psychological Measurement, 65(1), 140-154.

Magalhães, P. (2011). Comportamento alimentar, estado nutricional e imagem corporal de estudantes de nutrição: aspetos psicossociais e percurso pedagógico [PhD thesis]. São Paulo: Universidade Estadual Paulista.

Magdalena, K., \& Julie, A. (2012). Body image dissatisfaction among food-related degree students. Nutrition \& Food Science, 42(3), 139-147.

Mahn, H. M., \& Lordly, D. (2015). A review of eating disorders and disordered eating amongst nutrition students and dietetic professionals. Canadian Journal of Dietetic Practice and Research, 76(1), 38-43.

Mata, F., Verdejo-Roman, J., Soriano-Mas, C., \& Verdejo-Garcia, A. (2015). Insula tuning towards external eating versus interoceptive input in adolescents with overweight and obesity. Appetite, 93, 24-30.

Mealha, V., Ferreira, C., Guerra, I., \& Ravasco, P. (2013). Students of dietetics \& nutrition; a high risk group for eating disorders? Nutrición Hospitalaria, 28(5) $1558-1566$

Mehr, R. J., Clemens, L. H., Roach, R. R., \& Beech, B. M. (1997). Prevalence of eating disorders in dietetic and other health-related majors: A study of college students. Journal of the American Dietetic Association, 105(8), 29.

Mond, J. M., \& Hay, P. J. (2008). Public perceptions of binge eating and its treatment. International Journal of Eating Disorders, 41(5), 419-426.

Morgan, C. M., Vecchiatti, I. R., \& Negrão, A. B. (2002). Etiologia dos transtornos alimentares: aspectos biológicos, psicológicos e sócio-culturais. Revista Brasileira de Psiquiatria, 24(supl. III), 18-23.
Nergiz-Unal, R., Bilgic, P., \& Yabanci, N. (2014). High tendency to the substantial concern on body shape and eating disorders risk of the students majoring Nutrition or Sport Sciences. Nutrition Research and Practice, 8(6), 713-718.

Penz, L. R., Bosco, S. M., \& Vieira, J. M. (2008). Risco para desenvolvimento de transtornos alimentares em estudantes de Nutrição. Scientia Medica, 18(3) $124-128$.

Poínhos, R., Alves, D., Vieira, E., Pinhão, S., Oliveira, B. M., \& Correia, F. (2015). Eating behaviour among undergraduate students. Comparing nutrition students with other courses. Appetite, 84, 28-33.

Poínhos, R., Canelas, H., Oliveira, B. M. P. M., \& Correia, F. (2013). Desenvolvimento e validação de uma escala de auto-eficácia alimentar. Alimentação Humana, 19, 65-72.

Poínhos, R., Oliveira, B. M. P. M., \& Correia, F. (2015). Eating behaviour in Portuguese higher education students: The effect of social desirability. Nutrition, 31(2), 310-314.

Poínhos, R., Rowcliffe, P., Marques, A. R., Viana, V., Oliveira, B. M. P. M., \& Correia, F. (2013). Adaptação e validação das subescalas de controlo flexível e rígido do comportamento alimentar. Alimentação Humana, 19, 82-92.

Quaioti, T. C. B., \& Almeida, SdS. (2006). Determinantes psicobiológicos do comportamento alimentar: uma ênfase em fatores ambientais que contribuem para a obesidade. Psicologia USP, 17(4), 19.

Reinstein, N., Koszewski, W. M., Chamberlin, B., \& Smith-Johnson, C. (1992). Prevalence of eating disorders among dietetics students: Does nutrition education make a difference? Journal of the American Dietetic Association, 92(8), 949-953.

Ribas, RdC., Jr., Moura, M. L. Sd, \& Hutz, C. S. (2004). Adaptação brasileira da Escala de Desejabilidade Social de Marlowe-Crowne. Avaliação Psicológica, 3, 83-92.

Rosales, E. C. Ruíz, E. J. C. Martínez, M. A. M., \& Molina, O. M. (2012). Conductas alimentarias y sintomatología de trastornos del comportamiento alimentario en estudiantes de nutrición. Revista Mexicana de Trastornos Alimentarios, 3(1) 29-37.

Santos, Md, Meneguci, L., \& Mendonça, A. A. Fd (2008). Padrão alimentar anormal em estudantes universitárias das áreas de Nutrição, Enfermagem e Ciências Biológicas. Ciência et Praxis, 1(1), 1-4.

Schachter, S. (1968). Obesity and eating. Science, 161(3843), 751-756.

Shannon, B., Bagby, R., Wang, M. Q., \& Trenkner, L. (1990). Self-efficacy: A contributor to the explanation of eating behaviour. Health Education Research 5(4), 395-407.

Snoek, H. M., van Strien, T., Janssens, J. M., \& Engels, R. C. (2007). Emotional, external, restrained eating and overweight in Dutch adolescents. Scandinavian Journal of Psychology, 48(1), 23-32.

van Strien, T. \& Bazelier, F. G. (2007). Perceived parental control of food intake is related to external, restrained and emotional eating in 7-12-year-old boys and girls. Appetite, 49(3), 618-625.

van Strien, T., Herman, C. P., \& Verheijden, M. W. (2012). Eating style, overeating and weight gain. A prospective 2-year follow-up study in a representative Dutch sample. Appetite, 59(3), 782-789.

Tapadinhas, A., \& Ribeiro, J. L. P. (2012). Validação da Escala de Ingestão Compulsiva (BES), um estudo com uma amostra de obesos portugueses. Actas do 9. ${ }^{\circ}$ Congresso Nacional de Psicologia da Saúde, 1331-1336.

Torresani, M. E. (2003). Conductas alimentarias y prevalencia del riesgo de padecer de trastornos alimentarios en estudiantes de nutrición. Revista Española de Nutrición Comunitaria, 9(1), 30-33.

Verstuyf, J., Patrick, H., Vansteenkiste, M., \& Teixeira, P. J. (2012). Motivational dynamics of eating regulation: A self-determination theory perspective. The International Journal of Behavioral Nutrition and Physical Activity, 9(21).

Viana, V. (2002). Psicologia, saúde e nutrição: contributo para o estudo do comportamento alimentar. Análise Psicológica, 4(20), 611-624.

Viana, V., \& Sinde, S. (2003). Estilo alimentar: adaptação e validação do Questionário Holandês do comportamento alimentar. Psicologia: Teoria, Investigação e Prática, $1,59-71$.

Westenhoefer, J. (1991). Dietary restraint and disinhibition: Is restraint a homogeneous construct? Appetite, 16(1), 45-55.

Westenhoefer, J., Broeckmann, P., Munch, A. K., \& Pudel, V. (1994). Cognitive control of eating behaviour and the disinhibition effect. Appetite, 23(1), 27-41.

Westenhoefer, J., Stunkard, A. J., \& Pudel, V. (1999). Validation of the flexible and rigid control dimensions of dietary restraint. International Journal of Eating Disorders, 26(1), 53-64.

Wolfe, B. E., Baker, C. W., Smith, A. T., \& Kelly-Weeder, S. (2009). Validity and utility of the current definition of binge eating. International Journal of Eating Disorders, 42(8), 674-686.

World Health Organization. (2016). Body mass index. http://www.euro.who.int/en/ health-topics/disease-prevention/nutrition/a-healthy-lifestyle/body-massindex-bmi/ Accessed 26 June 2016.

Worobey, J., \& Schoenfeld, D. (1999). Eating disordered behaviour in dietetics students and students in other majors. Journal of the American Dietetic Association, 99(9), 1100-1102. 